\title{
The Implementation of Routine Conversation Technique to Improve Students' Speaking Ability in EFL Classroom
}

\author{
Mursyid \\ SMAN 2 Cianjur \\ mursyid.cianjur@gmail.com
}

\begin{abstract}
This study aims at investigating how the routine conversation technique (RCT) could improve the students speaking ability and also finding out the students' responses towards its implementation. The study was conducted at a State Senior High School in Cianjur, West Java, involving 30 students of XI Elective Class-5. It employed mixed methods design. For triangulation purpose and to answer the research questions, the data was collected through observation, interviews, and document analysis, taken from the result of speaking tests. The speaking pre-test and post-test was used to answer the students' speaking improvement. Additionally, to find out the students' responses, the observation and interviews were utilized. The RCT was implemented 3 times to deliver different interesting topics in the form of hortatory and narrative texts. The general result was the RCT could improve students' speaking ability significantly in EFL classroom. The students' responses to the use of the technique were also positive. Therefore, based on the findings, RCT is suggested to be applied as an alternative of the teaching technique to be implemented in the elective programs.
\end{abstract}

Keywords: Routine Conversation Technique (RCT), Mixed Method, English as a Foreign Language (EFL), Teaching Technique

\section{INTRODUCTION}

Speaking is one of the basic competences that should be mastered by English learners. However, many students encounter difficulties to speak English. They have anxiety and are lack of vocabulary (Indrianty, 2012). So, it is assumed that they do not understand what people say in conversation. Some other reasons behind students' difficulties to speak might come from the students' habits, such as either they have not the opportunity to express their feeling or they have not chance to practice in English speaking. Some previous studies in the efforts to improve students' speaking ability hes been done (see Efrizal, 2012; Oradee, 2012; Syafie, 2012). Those research journals were focus on improving speaking ability of students. Those researches took place in classrooms at schools. However, not all of those studies did the research based on lesson plan from syllabus in school curriculum except for research by Oradee (2012) which use 8 lesson plans and English speaking ability test. In speaking concept, many techniques have been offered to improve speaking skill among EFL learners. One of the suggested techniques is routine conversation technique which, is assumed, can solve those problems above. Thornbury and Slade (2006) explained that conversation is the informal and interactive talk between two or more people. To make conversation come to existence, this study focuses on routine conversation technique with the aims to investigate how the technique improve students' speaking ability and to find out the students' responses to this technique. It can be explained as one of speaking activities which aimed for interpersonal communication which people do very often among two people or more. However, routine conversation in this study is used as one of the techniques to increase the students' speaking ability. The term of daily routine means activities of inner-outer circles of speaking activities to fulfil the needs of students' speaking practice (Guiney, 2011).

However, routine conversation in this study was used as one of techniques to increase the students' speaking ability. This study was conducted in the English elective class in a senior high school which was integrated with the material of the day. Elective class was a special program from curriculum 2013 for students who want to learn EFL more intensively beside the regular class. In addition, 'integrated' means that the topic and the process of routine conversation which adjusted to the syllabus and material of the day.

The integrated technique allows the students feel enthusiastic, curious and easy to describe and to build the meaning in speaking class activity. In its implementation in EFL classroom, the teacher offers interesting topics in stimulating the students to give their opinion about the topic will be discussed. Before the activities being implemented, students should have learnt how to speak in daily routine conversation and be familiar with related vocabulary and grammar. Whereas, based on Brown (2007), the routine is used to display the everyday activities. However, both (Guiney, 2011) and Brown (2007) revealed the routine conversation as the daily and the everyday activities of speaking. Moreover, according to Tornbury (2005), the routine conversation is used to drill the students speaking activity in every classroom activity to stimulate students in using interesting topics. By means, Thornbury (2005) defined the routine as every classroom meeting. Classroom meeting in the research site follow the school schedule that is English elective class. It is used to be part of the curriculum 2013 where the students can choose their own interesting subject. The writer would like to take routine conversation term as a technique used by teacher as part of speaking activity to fulfil the need of students in exercise, speaking English. It has a goal to help students on minimal requirement. The minimal 
requirement is the improvement of their speaking English as a Foreign Language (EFL).

The writer would elaborate definition of routine conversation activities. First, routine is something done in daily activity and the exercises, done in the same way, and often repeated. Second, conversation is the informal, interactive talk between two or more people, which happens in real time spontaneously, has a largely interpersonal function, and in which conversation is one of the speaking activity and it is said as the most fundamental form of oral communication. Furthermore, routine conversation can be explained as one of speaking activities for interpersonal communication which people do very often between two or more people.

The study of routine conversation technique is purposed for senior high students' English as a Foreign Language (EFL) development. English as a Foreign Language is used in terms for English used in many non-native speaker counties. In this case, Indonesia is one of many countries that uses English as a Foreign Language especially English as a subject in schools. There are many problems face in the study of EFL eventhough the language is needed for international community service (Brown, 2007). One example of the problems is the limited time for weekly meeting for students. Elective subject in elective class is held by school to answer the limited meeting hour for EFL lesson hour in the school. This is one effort to fulfil the current implementation of curriculum 2013. Therefore, the study would show the collected data from the implementation of RCT.

\section{METHODS}

The method employed in this study was a mixed methods design with triangulation design (Cresswell, 2007; Sugiyono, 2010). Mixed methods are defined as a procedure to collect and to analyse the data by using two methods or more. In this case, the mixed methods used quantitative and qualitative research to get more information in collecting the data. This research method can be proved by the documents from speaking pre-test, treatment, speaking post-test, observation, and interview transcription. It also designed to explore intensively to the data collection. Thus, both of the quantitative and the qualitative methods complete each other in data collection (Cresswell, 2007). In collecting data from quantitative method, the pre-experimental design with one group pre-test and post-test is chosen. In qualitative method, the case study design is employed for its role.

In this research, there were some problems that had been discovered such as the effects of routine conversation in improving students' speaking ability and the students' responses to the routine conversation technique. The research site was one class in one senior high school in Cianjur. It was taken for the sample of the research because it was located in strategic location of the centre of Cianjur which can be used, with the assumption, as the represention of Cianjur Region.

The class which was taken was elective class where the students who want to learn English more. The elective class of English is one program from the school to help the students to increase their competence in English as a Foreign Language (EFL). Moreover, it involved 30 students who were willing to learn EFL more intensively beside their regular class. The materials were integrated the topic and the process of routine conversation, and had been adjusted to the school syllabus. Thus, the study focusing on improving students' speaking ability

The instruments employed in this study were; 1) documents analysis from speaking assessment instrument with the criteria behind the form of pre-test and post-test, 2) observation, and 3) Interview. The pre-test was conducted in order to diagnose the starting ability of students' speaking while the the post-test was used to compare the new information data after students have been given the treatment. The treatment consists of three meetings in 45 minutes for each meeting before class and integrated conversation with the material during next 45 minutes. The document of speaking assessment from pre-test and post-test was taken by oral test for every student in the shape of interview about their daily activities and their knowledge about the topic. The observation of this research was three meetings of classroom observation where the process was to scan the teacher and the students activities in classroom to the observation paper. In order to triangulate the research data, interview to six students had been conducted.

\section{RESULT AND DISCUSSION}

In this research, there were some problems that had been discovered such as the effects of routine conversation technique and students' responses to the technique. The case was begun with the findings of speaking pre-test and post-test. The pre-test and post-test were in the form of interview where individuals were called one by one to examine the certain testing (Thornburry, 2005). The total meetings were five meetings with two meetings for pre-test and post-test and three meetings were used for treatment of routine conversation technique implementation.

In pre-test, students were given a test paper which consisted of two parts. The first part was questions about daily activity consisted of five questions and the second part was table of today students' activity that. Then, the three meetings of the treatment were used for students with different topic and materials for every meeting. The number of treatment was only three meetings because the students of elective class had good starting point at their interest in English, their basic knowledge and skills about English.

After four meetings of research (1 pre-test, and 3 treatment teachings, including 3 observations), the post-test was held. According to Delucci (2014), post-test can inform the pedagogy development after the course evaluation. This post-test determined 'how far is either the improvement or the stagnancy' of students' speaking. The result of pre-test and post-test had significantly arisen after given treatment 3 times. The biggest score was gained by the subject no.17 with the post-test of 93 and pre-test of 82 . It means the subject has increased $11 \%$ to the maximum number. While the lowest score was gained by the subject no. 25 with score of post-test 
was 81 and the score of pre-test was 75 . The difference number of 81 minus 75 was 6 point or $6 \%$ to the maximum number. The students had well improvement after they were given the RCT.

The data analyzed using SPSS v.20 to examine the normality, the homogeneity, and the match t-test. The normality test of data is notified by using One-Sample Kolmogorov-Smirnov Test at significance 0.05. After being calculated, the data distribution was normal. It was normal because the data at significance $0.213>0.05$. The data of homogeneity was tested by ANOVA test of homogeneity of variances. The data showed that df was $n-1$; the sample 30 minus one equals 29 . Then, the significance was 0.555 while the alpha was at significance $5 \%$ or 0.05 . In other word, 0.555 $>0.05$ means the significance of homogeneity was bigger than 0.05 . If it was bigger, it means the calculated data was homogenous.

Hypothesis testing was to obtain $>\mathrm{t}$-critical $=13.29$ $>2.045$. This result showed mean of pre-test was 76.4333 and post-test was 86.2667. Standard deviation of pre-test is 3.8020 and standard deviation of post-test is 3.0618. The 2-tailed was 0.00. Therefore, the null hypothesis was rejected. It was indicating that routine conversation technique could improve students' speaking ability significantly in EFL classroom.

The students' responses were analyzed based on the data from observation and data interview. After the observation and interview, many facts were revealed. On the first meeting, almost all of the students were less active in the class. They looked unready and still looked nervous when the technique was introduced. So, on the second and third meeting of the study, students and teacher were learning to do conversation even though they were still accustomed with the practice.

Another fact found from the implementation of routine conversation was that students were enthusiastic and tried to communicate; but they still had limited vocabulary and hesitated to share their statement when discussing the topic. So, the teacher gave them some vocabularies to help them did the routine conversation. Some of students were assumed to be passive to state their own idea. It could be because they were still nervous and unprepared in communicating their ideas when speaking in routine conversation. The students' responses to the RCT after the treatment is compared to their problems based on the starting diagnostic (pre-test) data as shown by table 1 below:

\section{Table 1. Student's responses after RCT}

\begin{tabular}{|c|c|c|}
\hline No & $\begin{array}{l}\text { Students' speaking } \\
\text { problem before RCT }\end{array}$ & $\begin{array}{l}\text { Students' responses after } \\
\text { RCT }\end{array}$ \\
\hline 1. & $\begin{array}{lr}\begin{array}{l}\text { Students were less } \\
\text { active because }\end{array} \\
\text { of } \\
\text { nervous and unready }\end{array}$ & $\begin{array}{l}\text { Students had well } \\
\text { preparation, become active to } \\
\text { talk, enthusiastic, and try to } \\
\text { talk. }\end{array}$ \\
\hline 2. & $\begin{array}{l}\text { Students were passive to } \\
\text { state their own idea } \\
\text { because of their limited } \\
\text { vocabulary }\end{array}$ & $\begin{array}{l}\text { Students had being helped by } \\
\text { the teacher so their } \\
\text { vocabulary was increased for } \\
\text { the conversation. }\end{array}$ \\
\hline
\end{tabular}

Table 1, Cont.

3. Students were $\begin{aligned} & \text { Students did the conversation } \\ & \text { confused and difficult } \\ & \text { to show their } \\ & \text { speaking. }\end{aligned}$
$\begin{aligned} & \text { 4. Students had many had good content. } \\ & \text { distraction and many before } \\ & \text { pauses in speaking }\end{aligned}$
$\begin{aligned} & \text { Students had difficulty } \\ & \text { in finding the topic for } \\ & \text { speaking }\end{aligned}$
$\begin{aligned} & \text { important notes related to topic } \\ & \text { so they have been easier to } \\ & \text { speak. }\end{aligned}$

The research result was examined with interview to select the respondents. It was aimed at checking the improvement of students' speaking ability, not only on the statistical numbers, but also at the students' responses themselves. The question has been prepared for the interview with 15 structural questions for every respondent. The respondents who participate as interviewees were six students of elective class-5 which was chosen based on purposive sampling. The interviews were conducted in Bahasa Indonesia to make the process of collecting the data being maximized and the information from the respondents could be understood in full understanding.

\section{CONCLUSION}

Routine conversation technique (RCT) facilitated students to have more intensive English practice and it improved the students' speaking skills as well. The speaking skill improvement was proven by $t_{\text {obtain }} \geq t_{\text {critical }}=13.29$ $\geq 2.045$. The t-obtain was bigger than the t-critical. To go further, it is assumed that statistically, the gain number of the students' speaking skill which was documented on the assessment paper was influenced by the RCT significantly. It is also important to sum up that RCT implementation that had positive responses from students based on the three times observation and interviews. For example, RCT helped students to be well-prepared, be active to talk, increase their vocabulary, and be easier to speak. Therefore, based on the findings, RCT is suggested to be applied as an alternative of the teaching technique to be implemented in the elective programs.

\section{REFERENCES}

Brown, H. (2007). Principles of language language learning and teaching. NY: Pearson Longman.

Cresswell, J. W. (2007). Designing and conducting mixed method design (2nd Edition). New York: Sage Publication Inc.

Delucchi, M. (2014). Measuring students' learning in social statistic: A pre-test post-test study of knowledge gain. Journal of teaching sociology, volume 42.

Efrizal, D. (2012). Improving students' speaking skill through communicative language teaching method at Mts Jaalhaq, Sentot Ali Basa Islamic School of Bengkulu, Indonesia. International Journal of Social Science and Humanity Vol.2. 
Guiney, L. (2011). Education and dislexia translated. Friburg, Switzerland: A.I.A.P.P.

Indrianty, S. (2012). Students' anxiety in speaking English (A case study in one Hotel and Tourism College in Bandung). Unpublished. Bandung: UPI.

Oradee, T. (2012). Developing speaking skills using three communicative activities (Discussion, Problem Solving, and Role Playing) . International Journal of Humanaity and Science.

Sugiyono. (2010). Metode penelitian kuantitatif, kualitatif, $R \& D$. Bandung: Alphabeta.

Syafie, L. a. (2012). Simple conversation as speaking material for the fifth grade students. e-journal UNP.

Thornbury, S. (2005). How to teach speaking. Harlow, England: Longman.

Thornbury, S. \& Slade, D. (2006). Conversation: From description to pedagogy. Cambridge: Cambridge Teaching Library. 